\title{
CHRISTIAN THEOLOGY IN DIALOGUE WITH NORTHERN BASOTHO WORLD VIEW
}

JM Ramashapa

University of the North

\begin{abstract}
We South Africans come from a past where Christianity as a religion was virtually protected by the constitution of the country. Now that our interim constitution acknowledges the multi-religious nature of our country Christianity has to, without 'cop-out', be engaged meaningfully in dialogue with other religions. This paper is, therefore, an attempt to create a climate for such a dialogue between Christian theology and Northern Basotho world view. It firstly, gives a definition of the discipline socio-cultural anthropology and its methodology; secondly, the insight from this discipline is applied in the analysis of Northern Basotho world view; finally, the inferences drawn from the results of the analysis are converged with Christian theology in order to create a dialogue.
\end{abstract}

\section{Introduction}

We note with appreciation that in the interim constitution of the Republic of South Africa with democracy as its basis and philosophy, this country has not been declared religious in terms of a particular religion. Above all we are grateful that we still remain a religious country. This is assured by a very important element in the interim constitution, viz, the guarantee to have the same rights as well as the same position or status for all citizens, including religious freedom and freedom of worship.

The reality is that we come from the past where South Africa was virtually declared a single religion state. This was the time when Christianity enjoyed constitutional protection. This was the time when religious education at our schools was totally Christian. Definitely such an arrangement was biased and had a negative influence on the perception of other religions. While I concede that the Political Protection of Christianity was totally wrong I would today strongly warn any religion not to 'cop out' for the sake of being seen as tolerant or accommodating other religions. Religion is a matter of life or death. Just as we Africans do not gamble with life we cannot do the same (gamble) with our religion.

What we Christians can do, given the reality of the multi-faith situation of South Africa's 'rainbow people' is to level or create a playing field for proper and meaningful inter-religious dialogue.

Consequently this paper is an endeavour to create a climate for dialogue between Christian theology and Northern Basotho world view. This should serve as a case study for future dialogue with particularly other African religions.

Socio-cultural anthropology has proved that every social group throughout history has been moulded and influenced by its world view. This world view provides a fundamental orientation of beliefs, values, norms, symbols, etc. It is imperative, therefore, for us to make use of relevant insights gained from the scientific discipline of socio-cultural anthropology in the analysis of Northern Basotho world view.

Hereunder this paper will be divided into three main parts: firstly, it gives the definition of socio-cultural anthropology and its method of study; secondly, humanness as an element of Northern Basotho world view is discussed in detail and a summary of other elements 
(discussed and published by Ramashapa elsewhere ${ }^{*}$ ) is given, and lastly the inferences drawn from the results of the analysis are converged with Christian theology in order to create a dialogue.

\section{Definition of socio-cultural anthropology and its methodology}

Socio-cultural anthropology can be understood as a study of 'anthropos-human' in relation to culture and society. Sociology applies the concept 'culture' in a totally different way from what we are used to in our daily language and life. For a sociologist 'culture' is not simply referred to as artistic expression and achievements such as sculpture, poetry, music etc. Bierstedt (1957:136) says: 'Culture is that complex-whole that consists of everything we think and do and have as members of society'. This means that culture is the way in which anthropos lives in a society; a way in which anthropos expresses and sets up conditions for group living.

Anthropos everywhere in all history has been living in organised cultural groups which are referred to in sociology as society. Winick (1970:493) refers to society as a 'group of persons that lives as an entity and has its own culture; an organised aggregate of persons following a given way of life, persisting in time, and with a group consciousness'. This is how sociocultural anthropology as a scientific discipline takes the cultural perspective of anthropos in society. It attempts to understand a person by analysing his/her interaction with the social cultural group in which he/she is involved. The socio-cultural perspective acknowledges firstly, that anthropos lives in interaction in an organised society and secondly that culture is the 'common bond of understanding that makes such interaction possible' (Miller 1981:17).

\section{Northern Basotho world view}

Ramashapa (unpublished Master's degree dissertation") refers to Northern Basotho as 'sociologically defined as a group of people who are bound together by one culture (though with some variations here and there) and explicitly recognised by their language known as Northern Sesotho'. These people are found mainly in the Northern Transvaal Province. The conception of themselves as a social-cultural group stems from their common world view.

The Northern Basotho whom we speak of are sophisticated; they know that there are other people; they know that the world does not end up in the Northern Province. And yet these people are very conscious of their roots and history. Their whole way of life can only be described within the matrix of their world view.

Kraft (1979:53) defines world view as 'a central systematization of conceptions of reality to which the members of the culture assent and from which stems their value system'.

The implication here is that world view works like a controlling central computer centre in a given cultural milieu. This data based centre explains the origin of perceived reality, actualises and evaluates human interactions in society.

Among Northern-Basotho there is hardly any event or human relationship which cannot be explained in relation to the world view of their culture.

Their value system, therefore, could only be understood within the context of their world view and their culture. Ramashapa (paper to be published in NGTT) discusses basic elements of Northern Basotho as religion, concept of God (Supreme-Being) and ancestors, death and fear of Boloi-sorcery. These elements are deemed be very important for the understanding of the behaviour, actions and interactions of Northern-Basotho. In this paper we shall add and

*This paper has been accepted by Ned Geref Teologiese Tydskrif.

"Submitted at the University of the North in 1988. 
discuss in detail the concept of humanness in those elements. The main ideas from those elements are given in a summary.

\subsection{Anthropos-human being (Motho in Northern Sesotho)}

Pobee (1979:49) rightly describes the Western perception of a human being as based on Descartes' concept 'cogito ergo sum - I think, therefore I am'. This is a perception in which Western individualism finds its origin. Northern-Basotho anthropology is based on the expression 'Motho ke motho ka batho - a person is human in relation to other humans. A human being here refer to anything that has been created in the image of God (Gn 1:26). The catch value of the expression is found in the term 'humanness - botho in Sesotho, ubuntu in Zulu'. A person is not human unless he/she display's this humanness. Instead he/she is phoofolo - Northern Sesotho; isilwane - Zulu; meaning an animal.

This concept of human-being is inspired by the religion of the people (we discuss the religion and culture of the people as inseparable hereunder). For Northern-Basotho birth of a child in a family is the will of God and ancestors. The newly born baby is given a name to be identified with. If the child is born after more than two children who died at infancy this child is given a non-human name. The understanding here is that the child does not have a chance of becoming human. Names like Katse - cat, Matlakala - dirt, Molahloa - the wretched one etc are very common. But if there is no doubt that the child will live to become a human-being it is given a family name linked to the kinship.

A strong sense of belonging to a group is what characterises a human being. This sense of communal life has its roots in the common history and common cultural bond of the people. Each family or a clan has its own ancestors and a community also shares common ancestors. A community is therefore bound together by common allegiance to ancestors.

An individual Northern Mosotho person consists of flesh and dignity (serithi). This dignity or serithi is in actual fact what characterises a human being. Once a person behaves out of character then the serithi - dignity humanness is lost; and hence the expression 'selo se ga se motho', this thing (person) is not a human being.

The maintenance of one's humanness is through maintaining relationship and interacting with other humans. The game of interaction is played through upholding social values as provided by the common world view. One's belonging to a group is seen in one's presence at family or community funerals, wedding feasts and other gatherings.

The key concept of Northern Basotho anthropology is that of humanness, communal life and fellowship between humans and ancestors and God. In this communion God and ancestors provide all, including children and good health. We may conclude that Northern Basotho anthropology is 'humanitas', i.e. it is concerned with humanness.

\subsection{Preliminary summary of northern Basotho world view}

- The interim constitution of South Africa acknowledges the multi-religious nature of our society.

- The need for dialogue among different faiths has come forth as a challenge to Christian religion which was previously virtually protected by the constitution of the country.

- In order to create a dialogue between Bible education and Northern Basotho world view the insight provided by socio-cultural anthropology is utilised.

- An analysis of basic elements of Northern Basotho world view reveals that: 
- these people are communal entities; and the humanness of a person is defined in terms of his/her behaviour, what he/she does and his/her belonging in the community,

- $\quad$ there is a very thin line between the religion and culture of the people, and for that matter the thin line is only visible among Christians. Due to the hierarchical nature of the communities God as the Supreme-being can only be reached through ancestral mediation,

death, especially at an unripe age, is not considered to be a natural phenomenon. The prevalent belief is that there is a human enemy causative factor. Sorcerersbaloi are blamed for such deaths.

\section{The dialogue}

Following in the footsteps of Pobee (1979) and Kraft (1979) we now make an attempt to create a dialogue between Christian theology and Northern Basotho world view. Firstly, we define what Christian theology is all about and then proceed to interface points of convergence from the two teachings.

\subsection{What Christian Theology is About}

Christian theology is a process that is Bible centred. This means that the Bible is the Primary source of its information. Christianity as institutionalised in the Church is the custodian of this type of theology.

The purpose of Christian theology should be seen within the context of the ministry of the Church. Within this context Christian theology is the process through which the Church and Christian theologians attempt to meet a person where he/she is in relation to the teaching of Biblical text. Its objectives therefore are:

- to witness to God the Creator and Father (Gn 1:1ff. John 1:1ff); God the Redeemer and Son (Ex 3:7-8; Jn 3:16) and God the Holy Spirit (Lk 1:35; 4:8).

- to teach Ac 5:42; I Tm 4:11 all the world, to the whole creation (Mk 16:15) and among all other faiths (Ps 34:11, Mt 18:11-14; Jn 11:44).

- to serve - (Jn 12:26, Ac 2:41; Rm 12:11)

For Christian theology to achieve its goal and to contribute meaningfully to the continuation of wholesome functioning of human communities it has to address human existence in its totality.

Christ commissioned custodians of this theology to go into all cultures. The implication here is that Christian theology should have dialogue with all faiths in all cultures. It should not call people out of their cultural existence but it must meet them in their cultural milieu. This motivates us to create a possible dialogue between Christian theology and Northern Basotho world view.

\subsection{Interfacing Points of Convergence for Dialogue}

\subsubsection{Bible education approach to other cultures}

Church history has revealed that dialogue between Christianity and African traditional religions has been determined by economic power. Christianity with its more economic strength is dictating to economically poor African faiths. And therefore the relationship or dialogue is not necessarily on doctrinal or theological issues. We as African Christian theologians could succeed where Western theologies have failed if we always remember that we are primarily cultural beings before we are Christians. Our theology should employ models 
that are void of elite Western Christian imposition. The church as the custodian of Christian theology would be highly enriched if there could be a process of dialectical relation between Christianity and African cultures.

Pobee's (1979) contention is that Christianity hảs no right to lay claim to a finality of revelation. It would, therefore, be wrong to employ a tabula rasa model of dialogue. This is a model that sees nothing in other faiths and cultures on which Christianity can build. The dialogue that we seek to encourage between Christian theology and Northern Basotho world view is based on compatible elements of two faiths, viz Christian faith and Northern Basotho tradition faith. This dialogue appreciates and respects serious positive values of each faith. We, as Christian theologians enter this dialogue with the thesis that Christianity with its teaching has something to offer to all life situations.

For Pobee (1979) a meaningful dialogue between Christianity and other faiths could be achieved through an adaptation approach. This an approach that 'acknowledges that there is a whole heritage in the non-Christian culture and consciously attempts to come to terms with that heritage' (Pobee 1979:59). Adaptation approach does not suggest to 'cop out' but to encourage Christian theologians and teachers to revisit the purpose of Christ's incarnation. It is on the basis of a theology of incarnation that this paper seeks to create a dialogue between Christian theology and Northern Basotho world view. The whole incarnation phenomenon is an approach through which Christ identified himself with humans in order to have a dialogue aimed at human salvation.

The primary source of Christian theology is the Bible. And the purpose of Christian theology is to make known the dealings of God with humankind. We must accept that we speak of Christian theology in terms of Christianity because there would be no such theology if there had been no incarnation of the Logos. That is why Christian theology is Christ centred.

The content of Christian theology and its teaching must realize that God is equally concerned with earthly and cultural matters as He is with heavenly ones. What then are the points of convergence between Christian theology and Northern Basotho world view?

The first objective of Christian theology in dialogue with Northern Basotho world view should be to accept that humans are primarily cultural beings before they are Christians. All cultures as products and creators of humans are gifts from God and this calls for a mutual acceptance of one another's culture. Christian theology should approach people of cultures as truly human, full of faults and yet loved by God who created them in His image. God wants them to be heirs of His Kingdom. All humans have been created with equal values. Wingren (1979:36) rightly observes that '... a healthy and uninjured humanity is not an observable reality anywhere in the world. Rather within the framework of history, humankind has been realized at one point, namely in Jesus, and more precisely, in what is human in Jesus'.

Theologising among Northern Basotho should not be too simplistic; teaching only Bible stories and morality is not enough. The humanness of Jesus and his cultural being could be made relevant to Northern Basotho through employing Botho - humanness as conceptualised in their world view. The cross and resurrection should not be emphasised at the expense of creation; particularly the value and purpose of life here and now.

The body of a person is a manifestation of life and this body received its infinite value from God. Consequently no human-being has a right to mess-up one's own life or other people's life. A person's body and life must be respected and upheld in dignity and integrity.

\subsubsection{On God, Supreme-Being and ancestors}

It is the perception of cosmology that creates cultures and religions. If culture among other things is characterised by the way of life of people, their beliefs, norms, values etc then there is 
no dichotomy between cultures and religion among Northern Basotho. Ramashapa (Master's dissertation 1988) argues that the definition given by anthropologists (cf Mönnig 1979) that the origin of religion among Northern Basotho is a belief in 'spiritual beings' is foreign. The concept 'spiritual being' is non-existent in a traditional Northern Basotho culture and religion. Northern Basotho believe in the existence of ancestors (badimo) who are human being living in the other world. These are real people who are sometimes provided with real food, beer and other items that they may demand in one way or the other from the living.

Bible education fell on a fertile soil among Northern Basotho. Their belief in one Supremebeing opens avenues for a meaningful dialogue. Ancestors were never regarded as ultimate objects of their prayers. Instead they are seen as another level of their hierarchical community. This is a level attained after death at a ripe age. Ancestral communities is a continuation of earthly communities. One of their duties is to mediate between God and earthly people with an aim of keeping the earthly community together. Mediation is a way of life in kingship in Northern Basotho communities. Senior and special people in community are approached through mediation. This means of communication is necessary for resolving both implicit and latent conflict.

In kinship system belongingness forms the basis of mediation. It is only the one who belongs that can be entrusted with the confidentiality of the partners in communication. As the household leader act as a mediator (priest) between the family and ancestors, so it is the household ancestor member who mediates between the living and the Supreme-Being. The king mediates between the tribe and royal ancestors. There is no way that an outsider can become a priest or mediator of the enclosed group.

All New Testament books regard Jesus Christ event as a mediation phenomenon but this is only amplified by the letter to the Hebrews when it refers to Jesus as the High Priest. If Jesus' High Priesthood motif forms the main theme of the doctrinal section of the letter to the Hebrews then his mediation function can be appropriated for a dialogue between Northern Basotho ancestral function and Jesus' priestly function. Hebrews 1:1-2 says that 'In the past God spoke to our forefathers through the prophets at many times and in various ways, but in these last days he has spoken to us by his Son'. Speaking through suggests that due to God's nature he could not speak with human-beings face to face. Communication with God's junior partners in re-creation and redemption was through mediation.

\subsubsection{On fear of death and Baloi-sorcery}

According to Genesis death was pronounced to humankind as the ultimate punishment for $\sin$. Therefore fear of death is universal. But among Northern-Basotho death is not feared due to its nature, but is conceptualised as an evil caused by baloi-sorcerers.

This is why Boloi-sorcery is a thorny current issue among Northern Basotho today. People are blamed for deaths of other people through witchcraft. Witch-hunting and witch 'necklacing' (putting to death through fire from a tire doused with petrol around one's neck) hounds both communities and government. Northern Basotho world view conceptualises boloi as a reality. People live with this. Sekhukhune (1990:134) points out that the Northern Basotho ritual world covers a 'wide scope which entails a number of mystical and esoteric rituals'. Sorcery and witchcraft among Northern Basotho are mystical phenomena which could only be deciphered within the context of the ritualistic nature of these people. The truth about the existence of sorcery is relative for it is only intelligible to those communities who believe in it. Therefore witch-believing and labelling is a crucial point that needs to be brought into dialogue with Christian theology. 
Various contextualizations of Christian theology in African cultures should take a new dimension. The current deposition of the gospel by African theologians is motivated by Western philosophy which employs foreign concepts and thought. We suggest that one should, as Jesus did, first experience African reality. With this contextual experience one may proceed to interpret the Biblical text and then put the end results of the analysis into practice. For example one should find out what is it that people feel and see when they call someone a sorcerer. The findings then can be interpreted in the light of the objective of Bible education.

\section{Conclusion}

We argued that since the interim constitution of the country acknowledges the multi-faith nature of South African Society, there is a need for dialogue between different faiths, particularly between Christian theology and other faiths. A socio-cultural anthropological analysis of Northern Basotho world view reveals religio-cultural concerns which challenges Bible teachings. These concerns are not necessarily confined to Northern Basotho communities. Therefore points of convergence between Northern Basotho culture and Bible education have been particularly noted as models for dialogue between faiths.

The contribution made by Northern Basotho world view could be used to enrich and not dispose of Christian teaching. We urge Bible teachers and theologians to enter into dialogue with other faiths and cultures with a well articulated mission lest during the process Christian teaching becomes sterile. 


\section{BIBLIOGRAPHY}

Bierstedt, R 1957. The Social Order. New York: McGraw-Hill.

Kraft, CH 1979. Christianity in Cultures. Orbis: Maryknoll.

Ladd, GH 1975. Theology of the New Testament. Grand Rapids: Eerdmans.

Miller, ES 1981. Introduction to Cultural Anthropology. Englewood Cliffs: Prentice-Hall.

Mönnig, WO 1967. The Pedi. Pretoria: Van Schaiks.

Pobee, JS 1979. Towards an African Theology. Nashville: Abingdon.

Sekhukhune, PD 1990. Social meaning in North Sotho ritual Symbolism. S.Afr. Tydskrif Etnol, 1990 13(1), 30-32.

Taylor, JV 1963: The Primal vision. London: SCM.

Wingren, G 1979. Creation and Gospel. Toronto: Mellen. 